\title{
Detecção, transmissão e efeito de Xanthomonas campestris pv. campestris na qualidade fisiológica de sementes de brócolis
}

\author{
Nilvanira Donizete Tebaldi, Rita de Cássia Panizzi ${ }^{1}$, Rubens Sader ${ }^{2}$
}

${ }^{1}$ Prof ${ }^{a}$ Depto. Fitossanidade, FCAV - UNESP, Jaboticabal, SP. E mail: rpanizzi@fcav.unesp.br; ${ }^{2}$ Prof. Depto. de Produção Vegetal, FCAV UNESP, Jaboticabal, SP. E mail: rsader@fcav.unesp.br

Parte da Dissertação de Mestrado da primeira autora. FCAV/UNESP, Jaboticabal, SP (1999), bolsista do CNPq.

Data da chegada: 30/01/2004. Aceito para publicação em: 19/12/2006.

\section{RESUMO}

Tebaldi, N.D., Panizzi, R.de C., Sader, R. Detecção, transmissão e efeito de Xanthomonas campestris pv. campestris na qualidade fisiológica de sementes de brócolis. Summa Phytopathologica, v.33, n.3, p.290-293, 2007.

A detecção, a transmissão e o efeito de Xanthomonas campestris pv. campestris $(X c c)$ na qualidade fisiológica de sementes de brócolis (Brassica oleracea var. italica) foram avaliadas, a partir de sementes obtidas de plantas ("Baron, Flórida, Hana Midori Sakata, Precoce Piracicaba de Verão, Ramoso Santana e Sabre") inoculadas com a bactéria, em condições de campo. Para a detecção do patógeno nas sementes foram utilizados os meios de cultura semi-seletivos: SX ágar, NSCAA e BSCAA; a taxa de transmissão da bactéria pelas sementes às plântulas foi avaliada usando semeadura em areia $\mathrm{e}$ meio de cultura contido em tubo de ensaio. Para a avaliação da qualidade fisiológica das sementes foram realizados o teste padrão de germinação e os testes de vigor: envelhecimento acelerado, índice de velocidade de emergência, crescimento das plântulas e massa seca. De acordo com os resultados, o meio de cultura semiseletivo NSCAA foi mais eficaz para detectar Xcc em sementes de brócolis; não houve diferença significativa entre os genótipos na taxa de transmissão da bactéria pelas sementes e $X c c$ não afetou a germinação e o vigor das sementes.

Palavras-chave adicionais: podridão negra, Brassica oleracea var. italica, patologia de sementes.

\begin{abstract}
Tebaldi, N.D., Panizzi, R.C., Sader, R. Detection, transmission and effect of Xanthomonas campestris pv. campestris in the physiological quality of broccoli seeds. Summa Phytopatologica, v.33, n.3, p.290-293, 2007.

The detection, transmission and the effect of Xanthomomas campestris pv. campestris (Xcc) in the physiological quality of broccoli seeds were evaluated. The seeds were obtained from inoculated field plants ('Baron', 'Flórida', 'Hana Midori Sakata', 'Precoce Piracicaba de Verão', 'Ramoso Santana' and 'Sabre' genotypes) with the bacterium. For the seed pathogen detection the semi-selective medium were used: starch for xanthomonads (SX) agar, nutrient starch cycloheximide antibiotic agar (NSCAA) and basal starch cycloheximide antibiotic agar (BSCAA); the

bacteria seeds transmission percentage was evaluated using sand and test tube. The physiological seed quality was evaluated by the standard germination and vigor tests: the accelerated aging, speed of emergence, seedling growth and seedling dry weight. The semiselective medium NSCAA was more efficient to detect $X c c$ from broccoli seeds; there was not significant difference among genotypes regarding the percentage of bacteria transmissed by seeds percentage; although, Xcc can be disseminated by seeds, it did not affect both seed germination and vigor.
\end{abstract}

Additional Keywords: black rot, seed pathology, Brassica oleracea var. italica

A podridão negra, causada por Xanthomonas campestris pv. campestris $(X c c)$, é a doença de maior importância em Brássicas, ocorrendo em todo o mundo (10). A sobrevivência da bactéria se dá principalmente através das sementes, constituindo-se em importante fonte de inóculo primário, uma vez que poderá dar início ao ciclo da doença. Várias técnicas são utilizadas para detectar e identificar Xcc em sementes de Brássicas, como o uso de anticorpos mono (3) e policlonais em combinação com a microscopia de fluorescência (6), ELISA (1) e plaqueamento do extrato de sementes em meio de cultura semi-seletivos (5). Assim, o objetivo do presente trabalho foi selecionar meio de cultura semi-seletivo mais eficiente para detecção de Xcc em sementes de brócolis; avaliar a taxa de transmissão da bactéria através das sementes e verificar o efeito $X c c$ na qualidade fisiológica das mesmas.

As sementes infectadas com $X c c$ por meio da inoculação foram obtidas utilizando-se 6 genótipos de brócolis (Baron, Flórida, Hana Midori Sakata, Precoce Piracicaba de Verão, Ramoso Santana e Sabre), os quais foram transplantados para o campo, num total de 24 plantas por genótipo. As inoculações por aspersão foram realizadas nos estágios 5 e 6 de crescimento da planta, em 12 plantas de cada genótipo, utilizando-se suspensão bacteriana com $10^{9} \mathrm{ufc} / \mathrm{mL}$. As outras 12 plantas não foram inoculadas, e empregadas como testemunhas. Após 5 meses do transplante procedeu-se a colheita das sementes.

Para a detecção da bactéria $X c c$, as sementes foram desinfestadas com hipoclorito de sódio a $1 \%$, por 3 minutos e plaqueadas nos meios de cultura semi-seletivos (9) SX Agar, BSCAA, e NSCAA. Foram utilizadas 5 repetições, sendo a repetição representada por uma placa com 10 sementes, incubadas à temperatura ambiente $\left(26-31^{\circ} \mathrm{C}\right) . \mathrm{O}$ experimento constou de um esquema fatorial com 6 genótipos $\mathrm{x} 3$ 
Tabela 1. Detecção de Xanthomonas campestris pv. campestris em sementes de brócolis oriundas de plantas inoculadas em condições de campo, usando três meios de cultura semi-seletivos,. Jaboticabal - SP.

\section{GENÓTIPOS}

\section{Sementes Infectadas}

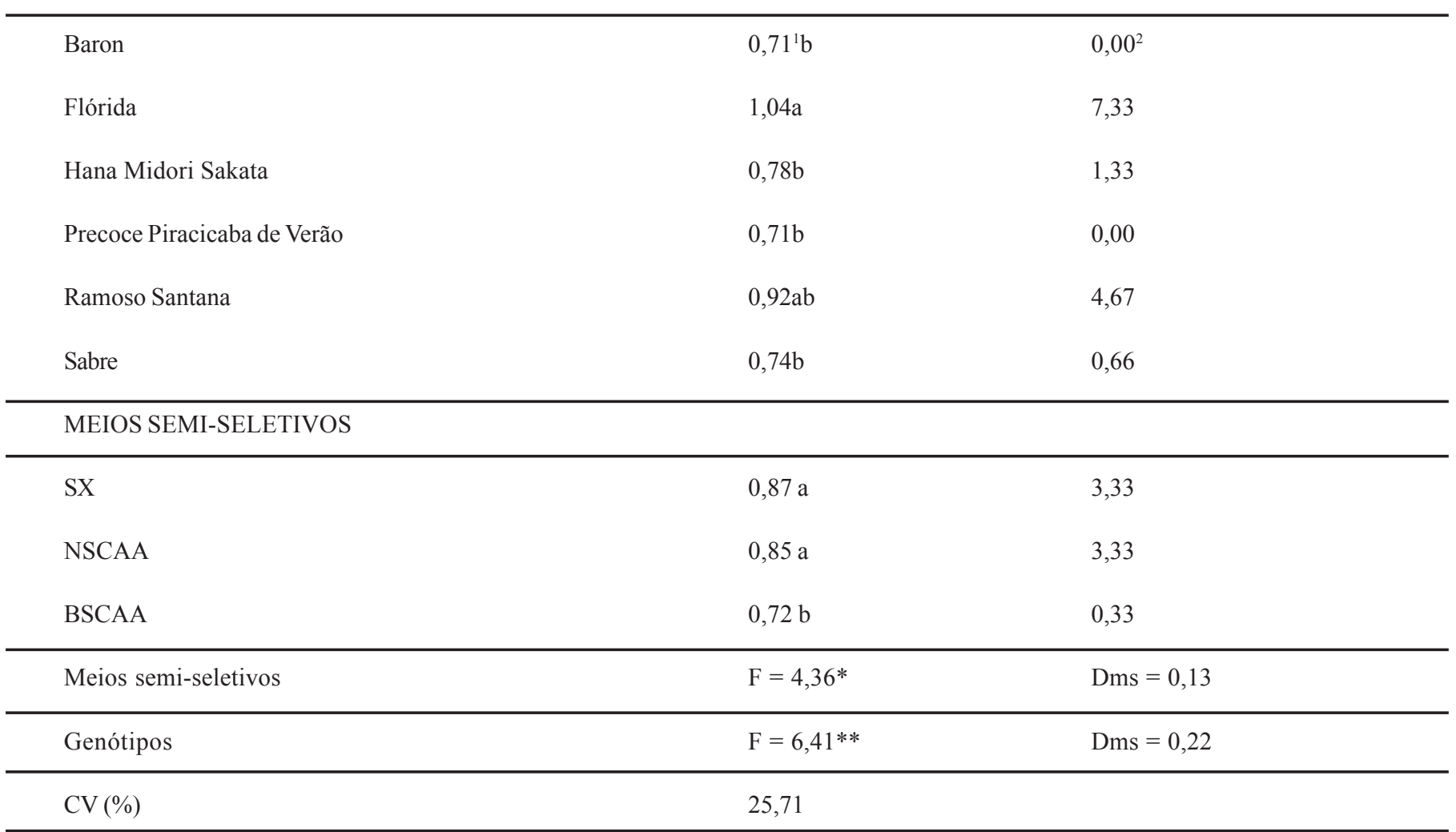

Médias seguidas por mesma letra, não diferem significativamente entre si a 5\% de probabilidade, pelo teste de Tukey

Dados transformados em $(\mathrm{x}+0,5)$

${ }^{2}$ Médias em \% (dados originais)

** Dados significativos a $1 \%$ de probabilidade;

* Dados significativos a $5 \%$ de probabilidade.

meios de cultura. Os dados foram transformados em $(x+0,5)^{1 / 2}$ e as médias comparadas pelo teste de Tukey a $5 \%$ de probabilidade.

A taxa de transmissão de $X c c$ pelas sementes foi avaliada, usando tubos de ensaio contendo ágar-água e caixas com areia esterilizada. Foram analisadas 50 sementes de cada genótipo, para cada método. A avaliação da porcentagem de transmissão foi feita 10 dias após a semeadura, através da contagem de plântulas, que apresentavam cotilédones com os bordos escurecidos, confirmado pelo teste de exsudação bacteriana. Foi avaliada também emergência de plântulas, em porcentagem. O experimento constou de um esquema fatorial com 6 genótipos x 2 métodos de detecção da bactéria. Para a análise estatística de emergência das plântulas e para a transmissão, as médias foram comparadas pelo teste de Tukey, a $5 \%$ de probabilidade.

O teste padrão de germinação foi realizado de acordo com as Regras para Análise de Sementes (2), utilizando 4 repetições de 50 sementes. A porcentagem do teor de água inicial das sementes foi determinada usando 2 repetições, pelo método da estufa a +105 ${ }^{\circ} \mathrm{C}$, por $24 \mathrm{~h}$. O experimento foi montado em esquema fatorial $6 \times 2$ (6 genótipos $\mathrm{x}$ inoculadas e não inoculadas). Para análise estatística da porcentagem de germinação as médias foram comparadas pelo teste de Tukey a $5 \%$ de probabilidade.

Para o teste de envelhecimento acelerado, 1,5 g de sementes (aproximadamente 250 sementes) foram colocados em caixa tipo "gerbox" e levados para câmara de envelhecimento por 48 horas, à temperatura de $45^{\circ} \mathrm{C}$ e umidade relativa de $100 \%$. Em seguida foram realizados o teste padrão de germinação e o teor de água das sementes.

Para determinar o índice de velocidade de emergência as plântulas que apresentavam $2 \mathrm{~mm}$ de radícula foram aferidas em dias alternados, até a última contagem (4), sendo calculado a seguir o índice de velocidade de emergência pela fórmula: $\mathrm{IVE}=\mathrm{G}_{1} / \mathrm{N}_{1}+$ $\mathrm{G}_{2} / \mathrm{N}_{2}+\ldots \ldots \mathrm{G}_{\mathrm{n}} / \mathrm{N}_{\mathrm{n}}$. $\left(\mathrm{G}_{1}=\right.$ número de plântulas que apresentavam $2 \mathrm{~mm}$ de emissão de radícula e $\mathrm{N}_{1}$, = número de dias após a instalação do teste). Após 10 dias da contagem do teste padrão de germinação foi avaliado o crescimento das plântulas através do comprimento médio total do hipocótilo e da raiz primária, avaliando-se 10 plântulas, de cada repetição. Os resultados foram expressos em centímetros, através da média aritmética de cada repetição. Para a determinação da massa seca foram utilizados 10 hipocótilos e 10 raízes primárias, acondicionados em latas de alumínio e levados para secar em estufa de circulação forçada de ar, regulada a $70{ }^{\circ} \mathrm{C}$, aproximadamente, até obtenção de massa constante. $\mathrm{O}$ experimento foi montado em esquema fatorial $6 \times 2$ e as médias comparadas pelo teste de Tukey a $5 \%$ de probabilidade.

O genótipo Flórida (Tabela 1) foi o que apresentou maior incidência (7,33\%) do patógeno nas sementes, porém não diferiu do genótipo Ramoso Santana (4,67\%). A incidência nos genótipos Sabre (0,66\%), Hana Midori Sakata (1,33\%) e Ramoso Santana (4,67\%) diferiram apenas da incidência no genótipo Flórida. A bactéria não foi detectada 


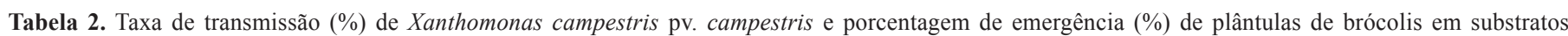
de areia e meio de cultura, provenientes de sementes inoculadas. Jaboticabal - SP.

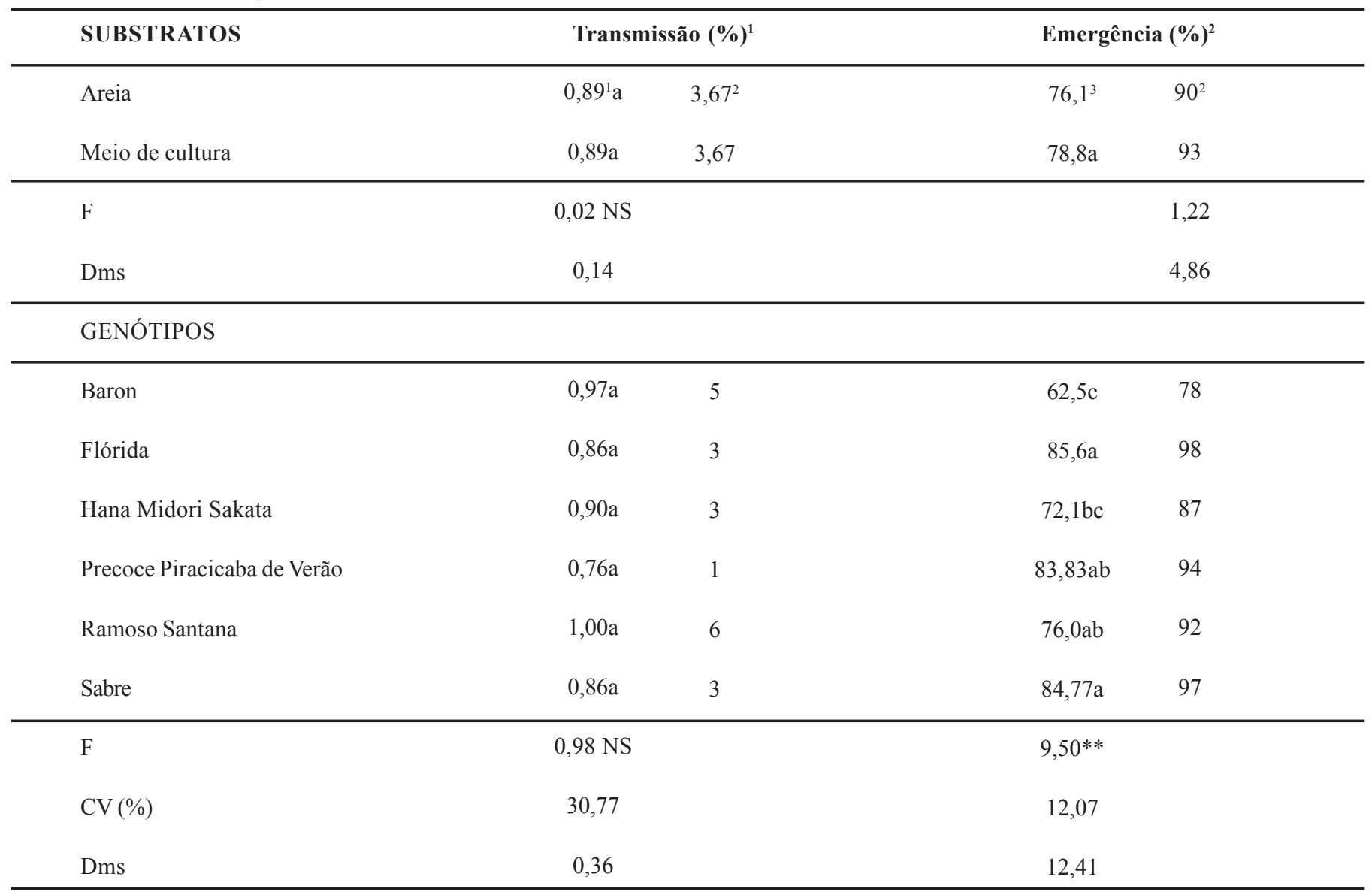

Médias seguidas por mesma letra nas colunas, não diferem significativamente entre si, a $5 \%$ de probabilidade, pelo teste de Tukey,

${ }^{1}$ Dados transformados em $(\mathrm{x}+0,5)^{1 / 2}$

${ }^{2}$ Médias em \%, dados originais.

${ }^{3}$ Dados transformados em arco-seno $(\mathrm{x} / 100)^{1 / 2}$

NS = não significativo a $5 \%$ de probabilidade,

** Dados significativos a $1 \%$ de probabilidade.

nas sementes dos genótipos Precoce Piracicaba de Verão e Baron. Os meios de cultura semi-seletivos NSCAA (3,33\%) e SX ágar (3,33\%) foram mais eficientes na detecção de Xcc em sementes de brócolis e diferiram significativamente do meio BSCAA (0,33\%). Embora, o meio NSCAA não tenha diferido do meio SX ágar, deve ser o recomendado, pois possibilitou melhor recuperação do patógeno, maior facilidade de visualização e identificação das colônias bacterianas formadas e o seu preparo é mais simples do que os demais. A detecção de $X c c$ em sementes usando meio de cultura é um método mais rápido, de fácil execução, mais seguro e mais sensível do que os testes em plântulas (7).

Para a taxa de transmissão de $X c c$ através das sementes e emergência de plântulas, não houve diferença entre os substratos areia e meio de cultura em tubo de ensaio (Tabela 2). Também não houve diferença entre os genótipos na porcentagem de transmissão do patógeno (1 a $6 \%$ ). Testes utilizando plântulas têm como vantagens demonstrar a transmissão direta da bactéria pela semente (8). Os genótipos Flórida (98\%), Sabre (97\%), Precoce Piracicaba de Verão (94\%) e Ramoso Santana (92\%) (Tabela 2) apresentaram maior porcentagem de emergência de plântulas. Os genótipos Hana Midori Sakata (87\%) e Baron (78\%) foram os que apresentaram menor porcentagem de emergência de plântulas, porém Hana Midori
Sakata não diferiu dos genótipos Precoce Piracicaba de Verão e Ramoso Santana.

Não houve diferença significativa no teste padrão de germinação, entre as sementes dos genótipos não inoculados e inoculados com Xcc em condições de campo (Tabela 3).

Com relação ao vigor das sementes, na primeira contagem de germinação, teste de envelhecimento acelerado e teor de água, comprimento médio total das plântulas, do hipocótilo, da raiz primária e massa seca do hipocótilo (Tabela 3) não houve diferença significativa entre as sementes dos genótipos não inoculados e inoculados com Xcc. Para o índice de velocidade de emergência houve diferença entre os genótipos inoculados com $X c c$ e não inoculados. Os genótipos não inoculados apresentaram maior massa seca da raiz primária diferindo significativamente dos genótipos inoculados com Xcc.

De maneira geral não houve diferença significativa na qualidade fisiológica de sementes de brócolis entre os genótipos não inoculados e inoculados com $X c c$. Embora $X c c$ seja disseminada pelas sementes, sua qualidade fisiológica não foi afetada, neste trabalho. Entretanto, é importante salientar que a semente constitui fonte primária de inóculo, podendo ser transportada a longas distâncias, levando a ocorrência de epidemias. 


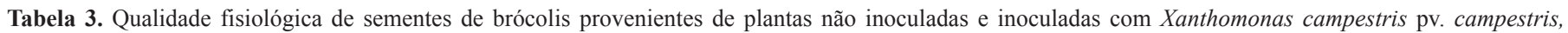
em condições de campo. Jaboticabal - SP.

\begin{tabular}{|c|c|c|c|c|c|}
\hline & Inoculada & Não Inoculada & $\mathrm{F}$ & $\mathrm{CV}(\%)$ & DMS \\
\hline Teste Padrão Germinação (\%) ${ }^{1}$ & $79,57^{2} \mathrm{a}$ & 80,10 a & $0,12 \mathrm{NS}$ & 6,61 & 3,09 \\
\hline Teor Água Inicial (\%) & 9,86 & 10,45 & $5,32 *$ & 6,22 & 0,56 \\
\hline $1^{\mathrm{a}}$. Germinação $(\%)^{1}$ & $79,30 \mathrm{a}$ & $80,01 \mathrm{a}$ & $0,18 \mathrm{NS}$ & 7,27 & 3,39 \\
\hline Envelhecimento Acelerado (\%) ${ }^{1}$ & 39,30 & 39,76 & $0,16 \mathrm{NS}$ & 9,91 & 2,30 \\
\hline Teor Água Env. Acelerado (\%) & 42,65 a & 42,74 a & $0,05 \mathrm{NS}$ & 2,37 & 0,90 \\
\hline Índice Velocidade Emergência & $24,11 \mathrm{a}$ & $23,55 \mathrm{~b}$ & $9,36 * *$ & 2,66 & 0,37 \\
\hline Comp. Médio Total Plântula (cm) & $14,07 \mathrm{a}$ & $14,53 \mathrm{a}$ & $3,18 \mathrm{NS}$ & 6,20 & 0,52 \\
\hline Comp. Médio Hipocótilo (cm) & 4,44 a & $4,49 \mathrm{a}$ & $0,30 \mathrm{NS}$ & 6,22 & 0,16 \\
\hline Comp. Médio Raiz Primária (cm) & 9,63 a & $10,04 \mathrm{a}$ & $2,97 \mathrm{NS}$ & 8,42 & 0,49 \\
\hline Massa Seca Hipocótilo (mg) & $0,0130 \mathrm{a}$ & 0,0136 a & $3,18 \mathrm{NS}$ & 8,25 & 0,0006 \\
\hline Massa Seca Raiz Primária (mg) & $0,0082 \mathrm{~b}$ & $0,0091 \mathrm{a}$ & $12,26 * *$ & 9,55 & 0,0005 \\
\hline
\end{tabular}

Médias seguidas por mesma letra nas linhas, não diferem significativamente entre si, a 5\% de probabilidade, pelo teste de Tukey,

${ }^{1}$ Dados transformados em arco-seno $(\mathrm{x} / 100)^{1 / 2}$,

${ }^{2}$ Valores obtidos com a média dos diferentes genótipos

NS = não significativo a $5 \%$ de probabilidade,

* Dados significativos a $5 \%$ de probabilidade,

** Dados significativos a $1 \%$ de probabilidade.

\section{REFERÊNCIAS BIBLIOGRÁFICAS}

1. Alvarez, A.M. Rapid identification of Xanthomonas campestris pv. campestris by Elisa. Plant Disease, St. Paul, v.69, n.12, p.1082-1086, 1985.

2. Brasil. Ministério da Agricultura. Secretaria Nacional de Defesa Agropecuária. Regras para análise de sementes. Brasília, 1992. $364 \mathrm{p}$.

3. Franken, A.A.L.M. Application of polyclonal and monoclonal antibodies for the detection of Xanthomonas campestris pv. campestris in crucifer seeds using immunofluorescence microscopy. Netherlands Journal Plant Pathology, Wageningen, v.98, n.2, p.95-106, 1992.

4. Nakagawa, J. Testes de vigor baseados na avaliação das plântulas. In: Vieira, R.D., Carvalho, N.M. (Ed.). Testes de vigor em sementes. Jaboticabal: FUNEP, 1994. p.49-85

5. Randhawa, P.S.; Schaad, N.W. Selective isolation of Xanthomonas campestris pv. campestris from crucifer seeds. Phytopathology, St. Paul, v.74, n.3, p.268-272, 1984.

6. Schaad, N.W. Use of direct and indirect immunofluorescence tests for identification of Xanthomonas campestris. Phytopathology, St. Paul, v.68, n.2, p.249-252, 1978.

7. Schaad, N.W. Correlation of Xanthomonas campestris pv. campestris in crucifer seeds. Seed Science Technology, Zurich, v.11, n.3, p.573-578, 1983.

8. Schaad, N.W. Detection of Xanthomonas campestris pv. campestris in crucifers. In: Saettler, A.W.; Schaad, N.W.; Roth, D.A. (Ed.). Detection of bacteria in seed and other planting material. St. Paul: APS Press, 1989. p.68-75.

9. Schaad, N.W.; Stall, R.E. Xanthomonas. In: Schaad, N.W. Laboratory guide for identification of plant pathogenic bacteria. 2.ed. St. Paul: APS Press, 1988. p.81-94.

10. Williams, P.H. Black rot: a continuing threat to world crucifers. Plant Disease, St. Paul, v.64, n.8, p.736-742, 1980. 